\title{
Astroniumxylon, Schinopsixylon, and Parametopioxylon n. gen. fossil woods from upper Cenozoic of Argentina: taxonomic revision, new taxon and new records
}

\author{
M. Jimena Franco, ${ }^{1,2 *}$ (1) Eliana Moya, ${ }^{1,2}$ Mariana Brea, ${ }^{1,2,3}$ and Camila Martínez Martínez ${ }^{1,2}$ \\ ${ }^{1}$ Laboratorio de Paleobotánica, Centro de Investigación Científica y de Transferencia Tecnológica a la Producción, Consejo Nacional de \\ Investigaciones Científicas y Técnicas CICYTTP (CONICET-Prov. ER-UADER), España 149, E3105BWA Diamante, Entre Ríos, \\ Argentina <jimenafr@gmail.com>, <li.196@hotmail.com>, <cidmbrea@gmail.com>, <camimartinez1@hotmail.com> \\ ${ }^{2}$ Facultad de Ciencia y Tecnología, Universidad Autónoma de Entre Ríos, Sede Diamante, Tratado del Pilar 314, 3105, Diamante, Entre \\ Ríos, Argentina \\ ${ }^{3}$ Cátedra de Paleobotánica, Facultad de Ciencias Naturales y Museo, Universidad Nacional de La Plata (FCNyM-UNLP), Calle 122 y 60 s/n, \\ 1900, La Plata, Buenos Aires, Argentina
}

\begin{abstract}
This paper presents new descriptions of Anacardiaceae fossil woods from the Ituzaingó Formation (late Cenozoic) at the Toma Vieja, Curtiembre, and Arroyo El Espinillo localities, Argentina. We describe eight silicified woods assigned to four different species in three genera, one of which, Parametopioxylon crystalliferum n. gen. n. sp., is new. Similarities between these three genera and the six Anacardiaceae species previously recorded from the late Cenozoic in northeastern Argentina are investigated using multivariate analysis techniques (correspondence and cluster analysis). Our study is based on 33 characters scored for 17 fossil specimens (10 Astroniumxylon Brea, Aceñolaza, and Zucol 2001; five Schinopsixylon Lutz, 1979; and two Parametopioxylon n. gen.) and four extant species (Astronium balansae Engl., Astronium urundeuva Engl., Schinopsis balansae Engl., and Metopium sp.). Our main goal is to determine the wood anatomical features useful for distinguishing among these species. Results of the multivariate analyses support the previous classification where Schinopsixylon is distinguished from Astroniumxylon by having exclusively paratracheal axial parenchyma, $\geq 30 \%$ multiseriate rays, and multiseriate rays that are $\geq 5$ cells wide and commonly $301-400$ $\mu \mathrm{m}$ in height. Additionally, we propose that Schinopsixylon heckii Lutz, 1979 is synonymous with S. herbstii Lutz, 1979. A diagnostic key for the fossil species studied is given. Wood anatomy of Anacardiaceae fossil woods from Argentina (late Cenozoic) suggests a warm, dry to semi-humid climate for this region, supporting previous studies.
\end{abstract}

\section{Introduction}

Anacardiaceae Brown, 1818, nom. cons., is a family of cosmopolitan distribution composed of evergreen or deciduous shrubs and trees with secretory canals in the leaves, bark, and, often, wood, mainly distributed in pantropical regions, with some elements found in temperate regions of Eurasia and South America (Muñoz, 2000). The family includes $\sim 80$ genera and nearly 880 species (Stevens, 2001-onwards). In Argentina, there are 33 extant species in six genera (Astronium Jacq., Lithraea Hook. and Arn., Mauria Kunth, Schinopsis Engl., Schinus L., Loxopterygium Hook. F.), six of which are endemic species of Schinus (Zuloaga and Morrone, 1999; Muñoz, 2000).

Anacardiaceous fossil palynomorphs and leaf impressions with affinities to Lithraea Miers., Schinus, and Astronium were recovered in the Miocene Paraná and Ituzaingó formations from northeastern Argentina (Anzótegui, 1990; Anzótegui and Aceñolaza, 2008; Franco et al., 2013). Recently, a fossil leaf type from the middle Miocene of Patagonia was described and assigned to

*Corresponding author the Anacardiaceae and shows a great similarity to Lithraea molleodes (Vellozo) Engler, 1876 (Passalia et al., 2019).

Moreover, in the last ten years, the number of anacardiaceous fossil woods found in the late Cenozoic of northeastern Argentina has increased significantly (Franco and Brea, 2008; Franco, 2009, 2011; Brea et al., 2010), with 17 taxa now reported (Table 1). Some Argentinean fossil woods resemble the extant genera Astronium, Schinopsis, and Schinus (Brea and Franco, 2013). Among them, Schinopsixylon was proposed by Lutz (1979) and contains two species: S. herbstii Lutz, 1979 and S. heckii Lutz, 1979 (Lutz, 1979; Brea, 1999; Brea et al., 2010; Franco, 2011). Astroniumxylon was erected by Brea et al. (2001) and contains three species: A. portmanii Brea, Aceñolaza, and Zucol, 2001; A. parabalansae Franco and Brea, 2008; and A. bonplandianum Franco, 2009 (Brea et al., 2001; Franco and Brea, 2008; Franco, 2009, 2011). In addition, Resinaxylon Pujana, an anacardiaceaous fossil wood resembling Schinus, was found in the Oligocene San Julián and Río Leona Formations (Patagonia, Argentina; Pujana, 2009; Martínez and Pujana, 2010).

Some salient secondary xylem features of the Anacardiaceae are: simple perforation plates (except in some species with both simple and scalariform plates); alternate intervessel pits; parenchyma paratracheal, scanty, vasicentric, or aliform, 
Table 1. List of OTUs selected for the multivariate analysis.

\begin{tabular}{|c|c|c|c|c|c|c|}
\hline OTUs & Acronym & Specimens & Collection & $\begin{array}{l}\text { Stratigraphic } \\
\text { formation }\end{array}$ & Geography locality & Reference \\
\hline 1 & ASPO1 & Astroniumxylon portmannii & MRVU 111 & Paraná & Villa Urquiza & Brea et al., 2001 \\
\hline 2 & ASPA1 & Astroniumxylon parabalansae & CIDPALBO-MEG 22 & Paraná & Toma Vieja & Franco \& Brea, 2008 \\
\hline 3 & ASPA2 & Astroniumxylon parabalansae & CIDPALBO-MEG 26 & Ituzaingó & Toma Vieja & Franco, 2009 \\
\hline 4 & ASPA3 & Astroniumxylon parabalansae & CIDPALBO-MEG 78 & Ituzaingó & Curtiembre & This paper \\
\hline 5 & ASPA4 & Astroniumxylon parabalansae & CIDPALBO-MEG 81 & Ituzaingó & Curtiembre & This paper \\
\hline 6 & ASBO1 & Astroniumxylon bonplandianum & CIDPALBO-MEG 27 & Ituzaingó & Toma Vieja & Franco, 2009 \\
\hline 7 & ASBO2 & Astroniumxylon bonplandianum & CIDPALBO-MEG 88 & Ituzaingó & Toma Vieja & This paper \\
\hline 8 & ASBO3 & Astroniumxylon bonplandianum & CIDPALBO-MEG 91 & Ituzaingó & Arroyo Espinillo & This paper \\
\hline 9 & SCHK1 & Schinopsixylon heckii & PB-CTES 4826 & "Salto Chico" & Concordia & Lutz, 1979 \\
\hline 10 & SCHK2 & Schinopsixylon heckii & LPPB 1281 & El Palmar & Península Gregorio Soler & Brea, 1999 \\
\hline 11 & SCHT1 & Schinopsixylon herbstii & PB-CTES 2925 & Ituzaingó & El Brete & Lutz, 1979 \\
\hline 12 & SCHK3 & Schinopsixylon heckii & CIDPALBO-MEG 12 & El Palmar & Santa Ana & Brea et al., 2010 \\
\hline 13 & SCHK4 & Schinopsixylon heckii & MAS-PALEOBOT 266 & Ituzaingó & Planta Potabilizadora Paraná & This paper \\
\hline 14 & PMET1 & Parametopioxylon crystalliferum & CIDPALBO-MEG 41 & Ituzaingó & Toma Vieja & This paper \\
\hline 15 & PMET2 & Parametopioxylon crystalliferum & CIDPALBO-MEG 46 & Ituzaingó & Toma Vieja & This paper \\
\hline 16 & ASPA5 & Astroniumxylon parabalansae & CIDPALBO-MEG 42 & Ituzaingó & Toma Vieja & Franco, 2011 \\
\hline 17 & ASPA6 & Astroniumxylon parabalansae & CIDPALBO-MEG 29 & Ituzaingó & Toma Vieja & This paper \\
\hline 18 & ASBAL & Astronium balansae & & & & Tortorelli, 1956 \\
\hline 19 & ASURN & Astronium urundeuva & & & & Tortorelli, 1956 \\
\hline 20 & SCHBA & Schinopsis balansae & & & & Tortorelli, 1956 \\
\hline 21 & METOP & Metopium sp. & & & & $\begin{array}{l}\text { Terrazas, 1994; } \\
\text { InsideWood, 2004-onwards }\end{array}$ \\
\hline
\end{tabular}

with marginal bands in some genera; rays mostly $2-3$ cells wide, but larger in some species, usually heterocellular; fibers with simple pits, sometimes septate; and intercellular canals in lots of genera (Metcalfe and Chalk, 1950; Terrazas, 1999; Giménez et al., 2015). The anatomical structure of the Anacardiaceae xylem is fairly homogeneous (Heimsch, 1942; Agarwal and Gupta, 2008; Gupta and Agarwal, 2008; Schweingruber et al., 2011), but some features have been proposed to differentiate genera from each other (Heimsch, 1942; Terrazas, 1994). Because multivariate analysis of comparative wood anatomy has been shown to be helpful in distinguishing species or groups of species in extant and fossil genera, such as in the Anacardiaceae, Nothofagaceae, Leguminosae, and Podocarpaceae (Terrazas and Wendt, 1995; Poole, 2002; Pujana et al., 2014a, b), we conducted a similar analysis to clarify the systematics of Anacardiaceae fossil woods recovered in southern South America.

The aims of this study are: (1) to make a taxonomic revision of the late Cenozoic Anacardiaceae fossil woods from northeastern Argentina; (2) to describe eight new silicified woods assigned to four different species of Anacardiaceae; (3) to determine anatomical variability and similarities among fossil Anacardiaceae woods found in the Ituzaingó, Paraná, El Palmar, and "Salto Chico" formations, and related extant genera using correspondence and cluster analyses to establish the taxonomic limits and the diagnostic characters in fossil taxa; and (4) to propose a key to distinguish species of Parametopioxylon new genus, Schinopsixylon, and Astroniumxylon from each other.

\section{Materials and methods}

Eight new wood specimens are described, all of which were collected from the Ituzaingó Formation at the Toma Vieja, Curtiembre and Arroyo El Espinillo localities (Fig. 1). These fossil woods are silicified and were thin-sectioned in transverse, tangential, and radial planes following standard techniques for petrified woods. The specimens are registered in the "Colección Paleobotánica del Laboratorio de Paleobotánica, CICYTTP
(CONICET-Prov. ER-UADER)" at Diamante city under the acronyms CIDPALBO-MEG for the fossil woods and CIDPALBO-MIC for the slides, and in the "Museo de Ciencias Naturales y Antropológicas Profesor Antonio Serrano" at Paraná city under the acronym MAS-PALEOBOT, Entre Ríos Province, Argentina. These sections were studied with a Nikon Eclipse E200 light microscope and photomicrographs were taken with a Nikon Coolpix S4 digital camera. For quantitative data, at least 25 measurements were taken. The mean values are shown, followed by minimum and maximum, in the description of each specimen. In addition, small fragments of wood were studied with a scanning electron microscope (SEM). The material was prepared for SEM by cutting a $1 \mathrm{~cm}^{3}$ block of wood, mounting it on SEM stubs without coating, and then observing under low vacuum using a Phenom Pro Desktop SEM scanning electron microscope at the Electron Microscope Laboratory (Laboratorio de Microscopía Electrónica-EMLAB "Dr. Domingo Liotta"), CICYTTP (CONICET-Prov. ER-UADER), Diamante, Entre Ríos, Argentina.

The descriptions of woods given below conform to the IAWA Hardwood List (IAWA Committee, 1989). For comparison with extant species, we used the InsideWood website and its coding (InsideWood, 2004-onwards; Wheeler, 2011) and references to classical descriptions of extant and fossil plants (Heimsch, 1942; Wagemann, 1948; Metcalfe and Chalk, 1950; Tortorelli, 1956; Terrazas, 1994, 1999; Terrazas and Wendt, 1995; Agarwal and Gupta, 2008; Gupta and Agarwal, 2008, Giménez et al., 2015). The InsideWood database provides coded wood anatomical descriptions based on the IAWA List of Microscopic Features (i.e., each anatomical feature has a number code). Most features are qualitative (showing presence [p] or absence [a]), but some are quantitative (Wheeler, 2011).

The systematic assignment follows the APG IV (2016). Relationships to extant and fossil groups were investigated by using the references found in bibliographic lists made by Gregory (1994), Gregory et al. (2009), and Kew Micromorphology Bibliographic web site (https://www.kew.org/epic/datasources. 


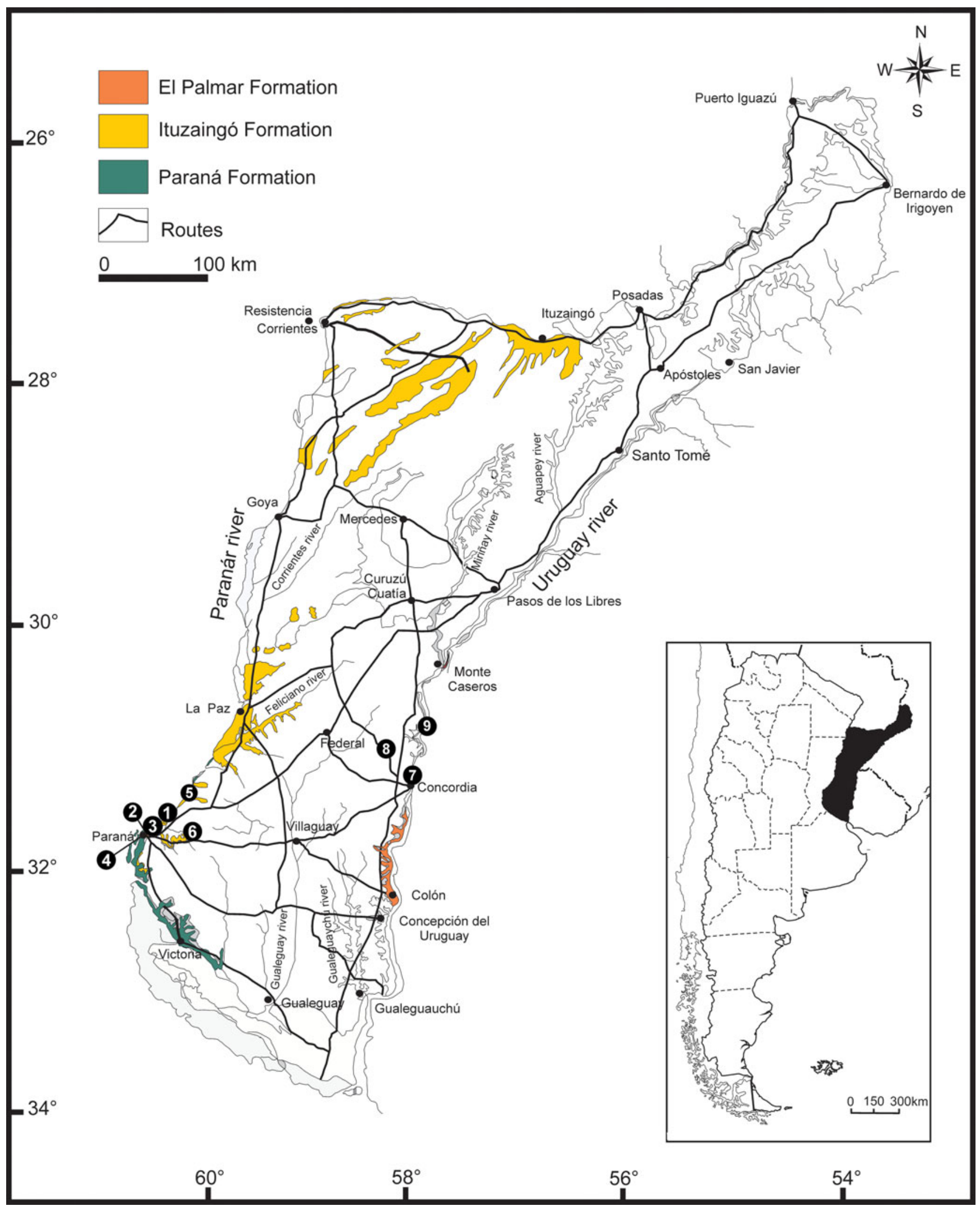

Figure 1. Geological map of the Mesopotamia Argentina showing the geological units (El Palmar, Ituzaingó, and Paraná formations) modified from Brea and Zucol (2011) and the fossil species localities: (1) Villa Urquiza, (2) Toma Vieja, (3) El Brete, (4) Planta Potabilizadora, (5) Curtiembre, (6) Arroyo El Espinillo, (7) Concordia, (8) Península Gregorio Soler, and (9) Santa Ana. 
htm). With respect to the nomenclature used in the new fossil woods, the specimens were assigned to fossil rather than modern genera because: (1) the fossils are represented only by an isolated organ for which the remainder of the plant is unknown, and (2) there is a convention to match taxonomic rank with geological time. In this case, the fossils were found in the Ituzaingó Formation (late Miocene?) and it has been proposed to use modern generic names from the Pliocene (Collinson, 1986; Avise and Johns, 1999). This protocol allowed us to unify criteria with previous work and facilitated the comparison of the material with other fossils.

In addition, a taxonomic revision based on 17 fossil specimens (10 Astroniumxylon, five Schinopsixylon, and two Parametopioxylon n. gen., including type species of each) and four extant species (Astronium balansae Engler, 1881; Astronium urundeuva (Allemão) Engler, 1881; Schinopsis balansae Engler, 1885; and Metopium sp.) was performed. The specimens examined are shown in Table 1.

The anatomical characters used in this study were considered in previous taxonomic papers to analyze phylogenetic and ecological aspects of the Anacardiaceae (Terrazas, 1994) and historical biogeography of Anacardiaceae based on fossil wood anatomy (Martínez-Millán, 2000). We used the characters that Terrazas (1994) and Martínez-Millán (2000) found useful for distinguishing Anacardiaceae species (Supplementary Material 1), to which we added the percentage of uniseriate, biseriate, and multiseriate rays.

Our complete Data Matrix (DM) consist of 21 binary and 12 multi-state characters, using the criteria of Crisci and López Armengol (1983). The characters used in the multivariate analysis with their corresponding states and codes and the DM are shown in Supplementary Material 1 and 2. If the fossil material was too badly preserved to identify the value of a character, the character was coded as "not comparable," and a question mark was used in the DM (Supplementary Material 2). Therefore, these character states were not included in the calculation process. The multivariate analyses were performed on a final DM that includes 22 wood anatomical characters because 11 were excluded either because they do not show variability, they are present in only one OTU, or the character can be highly influenced by environmental conditions (Baas and Wheeler, 2011, and references herein).

A Correspondence Analysis (CA) was performed to summarize similarities of anatomical variability among fossil specimens, and corroborate the accuracy of the systematic placement. Also, groups were classified by cluster analysis constructed using the UPGMA algorithm and based on Gower's distance matrix among OTUs. This coefficient can be used with a mixture of character types (binary, qualitative, and quantitative) as well as allowing missing values. All multivariate analyses were performed with the PAST software package version 2.17c (Hammer et al., 2001).

Repositories and institutional abbreviations. - Types and other specimens examined in this study are deposited in the following institutions and repositories: Museo Regional de Villa Urquiza (MRVU), Entre Ríos, Argentina; Colección Paleobotánica del Laboratorio de Paleobotánica, Centro de Investigación Científica y de Transferencia Tecnológica a la Producción-CICYTTP
(CONICET-Prov. ER-UADER) (CIDPALBO-MEG and CIDPALBO-MIC), Diamante, Entre Ríos, Argentina; Colección Paleobotánica "Dr. Rafael Herbts" (PB-CTES), Facultad de Ciencias Exactas y Naturales y Agrimensura, Universidad Nacional del Nordeste, Corrientes, Argentina; Colección Paleobotánica, Museo de La Plata (LPPB), La Plata, Argentina; Museo de Ciencias Naturales y Antropológicas "Profesor Antonio Serrano" (MAS-PALEOBOT), Paraná, Entre Ríos, Argentina.

\section{Systematic paleobotany}

All the specimens studied in this paper show diagnostic features of the Anacardiaceae: diffuse to semi-ring-porous, tyloses present, solitary, radial multiples, and in cluster vessels, simple perforation plates, alternate to opposite intervessel pits, parenchyma and ray-vessel pits with much reduced borders to apparently simple; pits horizontal or similar to intervessel pits in size and shape throughout the ray cells, predominantly paratracheal vasicentric parenchyma, heterocellular rays, presence of radial canals in multiseriate rays and prismatic crystals common (Metcalfe and Chalk, 1950; Terrazas, 1994, 1999; Gupta and Agarwal, 2008; Giménez et al., 2015).

Order Sapindales Berchtold and Presl, 1820

Family Anacardiaceae Brown, 1818, nom. cons.

Genus Parametopioxylon new genus

Type species.—Parametopioxylon crystalliferum n. gen. n. sp., by monotypy.

Diagnosis._-As for type species.

Occurrence.-Ituzaingó Formation (late Miocene? sensu Brunetto et al., 2013), outcropping at Toma Vieja, Entre Ríos Province, Argentina.

Etymology.-The generic name denotes the wood's resemblance to extant Metopium Browne, 1756.

Parametopioxylon crystalliferum new species Figures 2-4

Holotype.-CIDPALBO-MEG 41, CIDPALBO-MIC 691 from the Ituzaingó Formation, Toma Vieja, Entre Ríos Province, Argentina.

Paratypes._CIDPALBO-MEG 46, CIDPALBO-MIC 696.

Diagnosis.-Diffuse to semi-ring-porous; vessels without arrangement or in diagonal pattern, solitary, in radial multiples of 2-3 (4-5) or in clusters; vessel elements moderately numerous ( $>20$ per $\mathrm{mm}^{2}$ ) and narrow; very small to small, bordered, and alternate to opposite intervessel pitting; abundant tyloses; parenchyma and ray-vessel pitting with much-reduced borders to apparently simple (pits horizontal) or similar in size and shape to intervessel pits; exclusively simple perforation plates; rays mostly 1-3 seriate, heterocellular rays composed of procumbent and upright cells; 

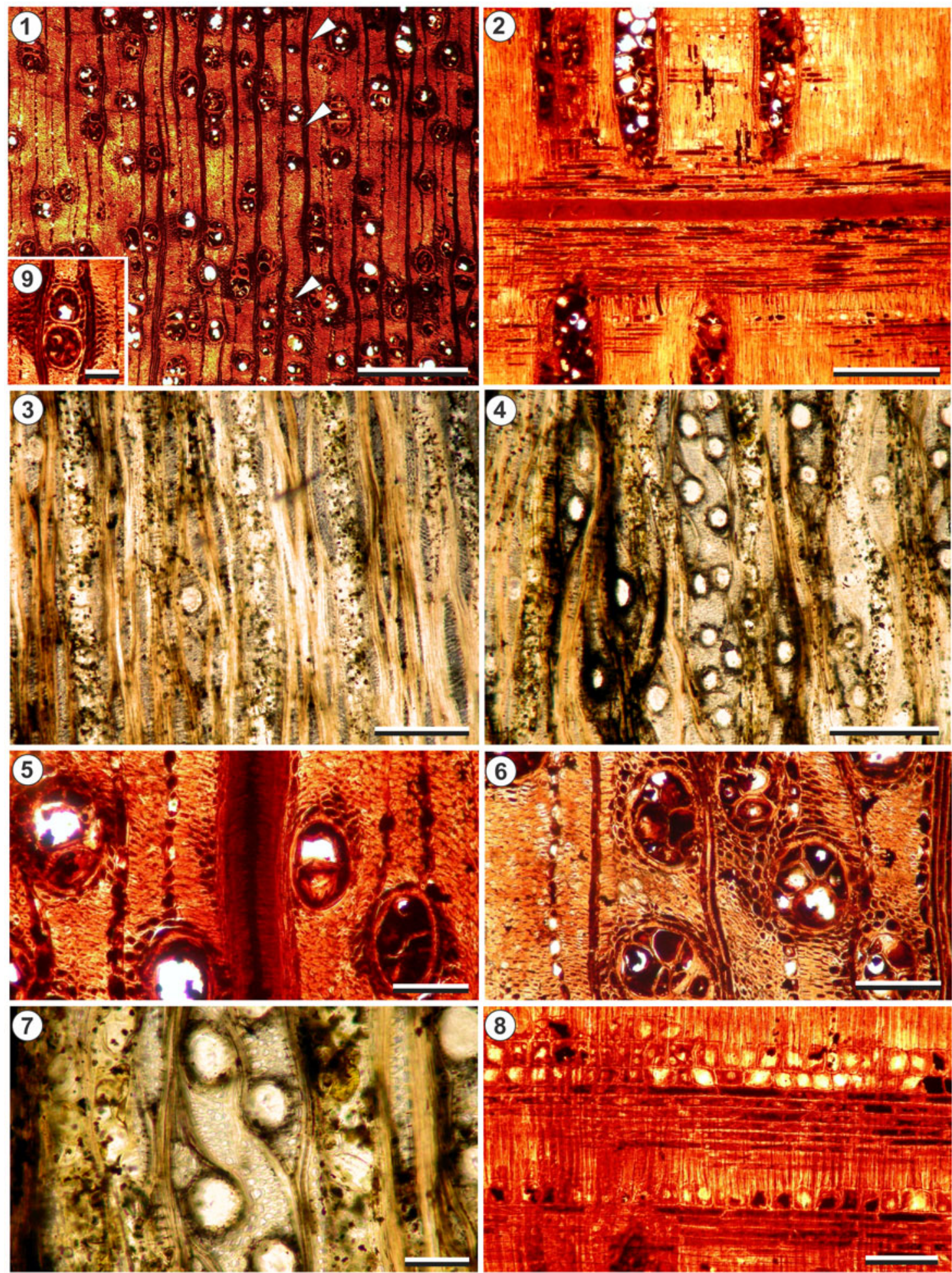

Figure 2. Parametopioxylon crystalliferum n. gen. n. sp., holotype CIDPALBO-MEG 41. (1) transverse section (TS) showing growth rings distinctly demarcated by marginal parenchyma (arrows), vessels, and parenchyma; (2) radial longitudinal section (RLS) showing a radial canal; (3, 4) tangential longitudinal sections (LTS) showing rays and vessels; note the numerous radial canals in multiseriate rays; $(\mathbf{5})$ TS with solitary vessels, vasicentric parenchyma, and rays; note the radial canal in a multiseriate ray; (6) TS showing vessels with tyloses, vasicentric, and confluent parenchyma, and rays; note prismatic crystals in ray cells; (7) detail of canals in multiseriate rays; (8) heterocellular rays with prismatic crystals in longitudinal radial section; (9) TS showing vessel with aliform parenchyma. Scale bars are (1) $500 \mu \mathrm{m}$; (2-8) $400 \mu \mathrm{m}$; (9) $100 \mu \mathrm{m}$.

some rays with one or more canals and $>500 \mu \mathrm{m}$ in height; fibers non-septate with simple bordered pits; axial parenchyma paratracheal predominantly vasicentric, sometimes confluent, aliform and apotracheal marginal; prismatic crystals mainly in chambered upright and/or square ray cells, and occasionally in procumbent cells. 

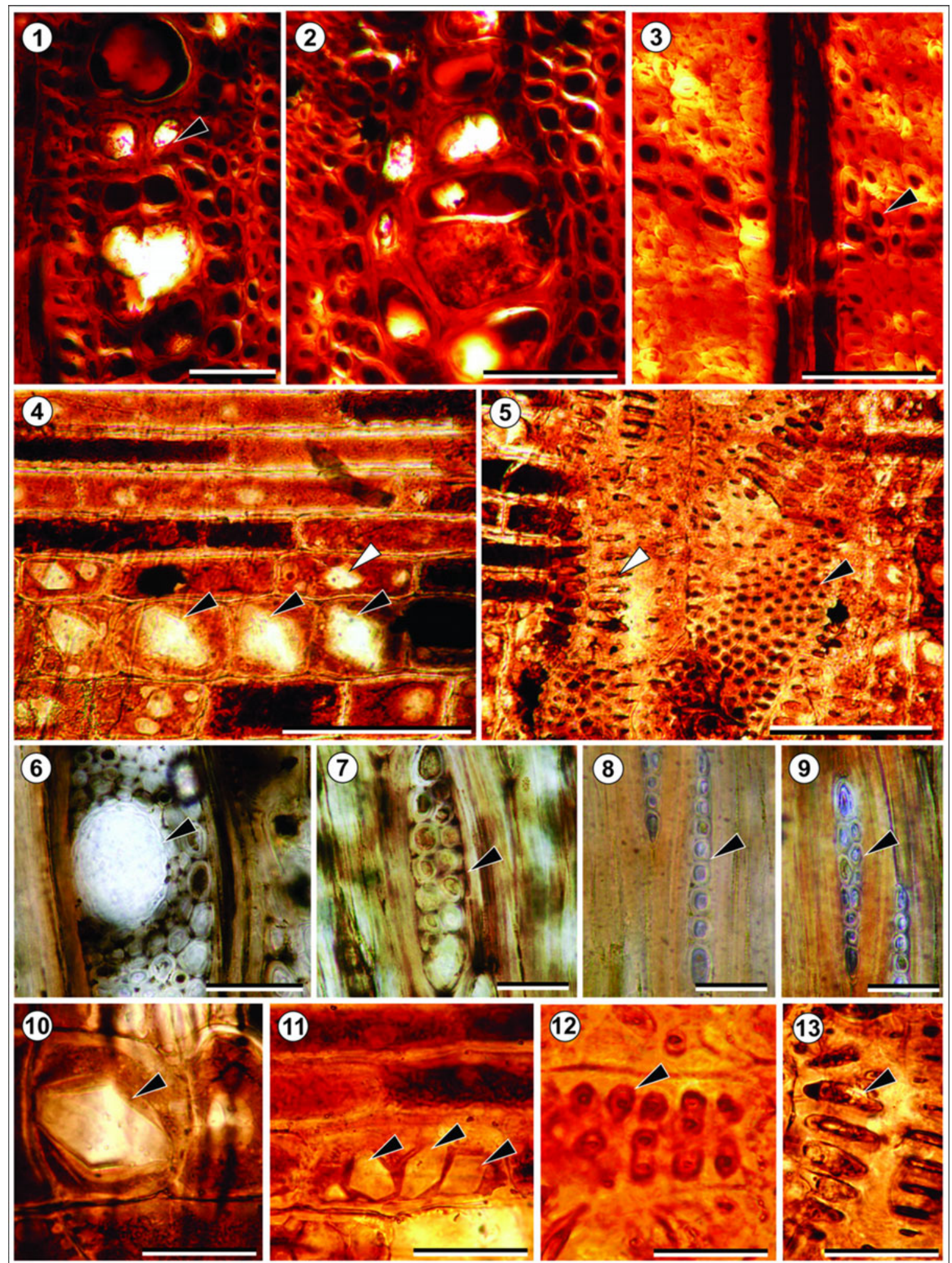

Figure 3. Parametopioxylon crystalliferum $n$. gen. n. sp., holotype CIDPALBO-MEG 41 (2), (4-13) and paratype CIDPALBO-MEG 46 (1), (3). (1, 2) Vessels in cluster (arrow); (3) fibers in TS, the arrow indicates marginal parenchyma; (4) detail of a heterocellular ray in LRS, the black arrows indicate prismatic crystals in upright cells and the white arrow in procumbent cells; (5) parenchyma and ray-vessel pitting horizontal (white arrow) and similar to intervessel pits in size and shape throughout the parenchyma cells (black arrow); (6) detail of a radial canal, in LTS; (7-9) uniseriate and biseriate rays (black arrows); (10) prismatic crystal in upright ray cell (black arrow); (11) prismatic crystals in procumbent ray cell (black arrows); (12) ray-vessel pitting similar to intervessel pits (black arrow); (13) parenchyma-ray pitting with much-reduced borders to apparently simple: pits horizontal. Scale bars are (1-6) $50 \mu \mathrm{m}$; (7-13) $20 \mu \mathrm{m}$. 


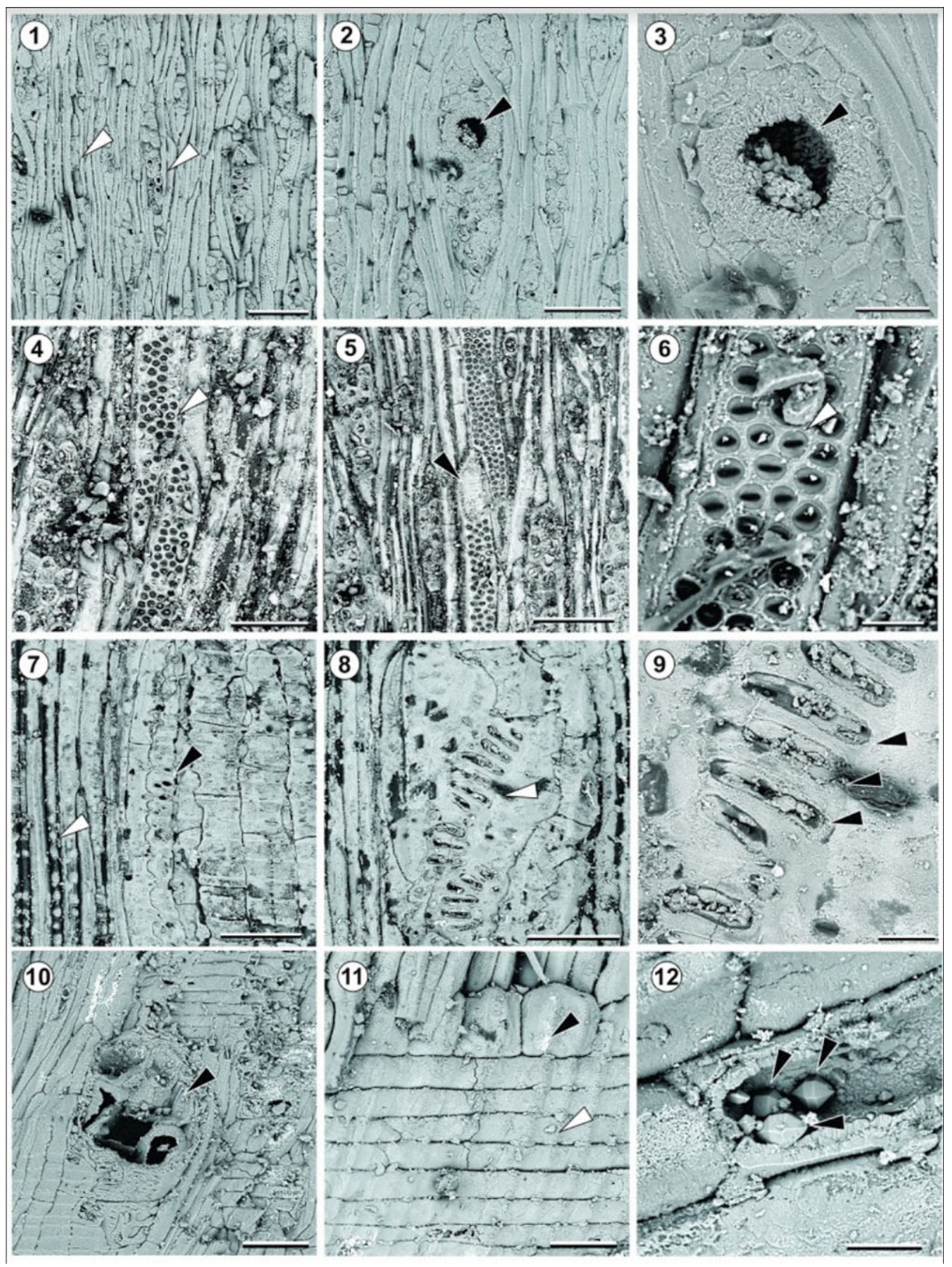


Figure 4. Parametopioxylon crystalliferum $\mathrm{n}$. gen. $\mathrm{n}$. sp. (1) LTS showing rays (white arrows) and vessels; (2), LTS showing multiseriate rays with radial canals (black arrow) and a vessel; $(\mathbf{3})$ detail of a radial canal (black arrow); $(\mathbf{4}, \mathbf{6})$ detail of bordered and alternate to opposite intervessel pits (arrows) $(\mathbf{5})$ simple perforation plate (black arrow) and alternate to opposite intervessel pits (white arrow) LTS. (7) parenchyma strand, parenchyma vessel pitting with much reduced border (black arrow) and fibers with minutely simple pits (white arrow); $(\mathbf{8 , 9})$ detail of horizontal parenchyma vessel pitting (arrows); (10) vessel with tyloses and simple perforation plate (black arrow); (11) detail of a heterocellular ray; (12), prismatic crystals in procumbent cells. Scale bars are $(\mathbf{1 , 2}) 100 \mu \mathrm{m},(\mathbf{3 , 1 1}) 30 \mu \mathrm{m},(\mathbf{4 , 7 , 8 )} 50 \mu \mathrm{m},(\mathbf{5}$, 10) $80 \mu \mathrm{m}$, and $(\mathbf{6 , 9 , 1 2}) 10 \mu \mathrm{m}$.

Occurrence.-Ituzaingó Formation (late Miocene?), outcropping at Toma Vieja, Entre Ríos Province, Argentina.

Description.-The fossil woods are in a very good state of preservation; the holotype has a diameter of $14 \mathrm{~cm}$ and is 13.5 $\mathrm{cm}$ long, and the paratype has a diameter of $16 \mathrm{~cm}$ and is 31 $\mathrm{cm}$ long. Growth rings are distinct, demarcated by marginal parenchyma (Figs. 2.1, 3.1). Vessels are diffuse to semi-ring-porous (Fig. 2.1). Vessels are randomly arranged or with a tendency to diagonal pattern (Fig. 2.1). Vessels are circular or oval in cross-section with frequent tyloses and other deposits (Figs. 2.1, 2.5, 2.6, 4.10). Some crystals are in tyloses (Fig. 4.10). Vessels are mainly solitary (45\%), in radial multiples of two $(25 \%)$, three $(10 \%)$, four $(6 \%)$, five $(3 \%)$, or more $(2 \%)$, and in clusters $(9 \%)$ (Figs. 2.1, 2.5, 2.6, 3.1, 3.2). The mean vessel tangential diameter is $94(34-127) \mu \mathrm{m}$, and the mean vessel radial diameter is $108(25-167) \mu \mathrm{m}$. There are, on average, 26 (19-31) pores per $\mathrm{mm}^{2}$. The mean vessel element length is $237(167-333) \mu \mathrm{m}$. The mean vessel wall thickness is $8(3-13) \mu \mathrm{m}$. Vessel elements have straight to oblique end walls (Fig. 4.4). Perforation plates are simple (Fig. 4.5, 4.10). Intervessel pitting has an average diameter of $6(2-8) \mu \mathrm{m}$, alternately to oppositely arranged, bordered with large lenticular apertures, and circular to oval in outline (Fig. 4.4-4.6). Parenchyma and ray-vessel pitting have much-reduced borders to apparently simple pits horizontal or are like intervessel pits in size and shape throughout the ray cells (Figs. 3.5, 3.12, 3.13, 4.7-8). Fibers are non-septate, rounded to polygonal in outline and arranged in radial rows (Fig. 3.3). Fibers are thin- to thick-walled; the mean fiber diameter is 13 (7-18) $\mu \mathrm{m}$ and the walls are 5 (3-6) $\mu \mathrm{m}$ thick. Minute simple pits are abundant, confined to radial walls (Fig. 4.7). Axial parenchyma is paratracheal, mostly vasicentric, sometimes confluent, lozenge-aliform and apotracheal marginal (Fig. 2.1, 2.5, 2.6, 2.9); 2-7 cells per parenchyma strand (Fig. 4.7). Rays are heterocellular. Body ray cells either are procumbent (3-30 rows of cells) with 1-4 rows of upright and/or square marginal cells, or are procumbent, square and upright mixed throughout the ray (Figs. 2.2, 2.8, 3.4, 4.11). Rays are uniseriate (23\%), biseriate $(35 \%)$, triseriate $(24 \%)$, tetraseriate $(6 \%)$, and wider with canals $(12 \%)$ (Figs. 2.3, 2.4, 3.6-3.9, 4.1, 4.2). There are 11 (7-15) rays per linear mm. They are $204(70-500) \mu \mathrm{m}$ high, $21(10-40) \mu \mathrm{m}$ wide, 46 (24-79) cells high, and 9 (6-12) cells wide (Fig. 2.3, 2.4). Some multiseriate rays have numerous canals (Figs. 2.4, 2.7, 3.6, 4.2, 4.3); rays with canals are sometimes $>1 \mathrm{~mm}$ high. Canals have a mean diameter of $56(25-80) \mu \mathrm{m}$. Mineral inclusions in the form of prismatic crystals are mainly in chambered upright and/or square ray cells, and occasionally in procumbent cells, and in tyloses (Figs. 2.8, 3.4, 3.10, 3.11, 4.12).
Etymology.-The specific name, crystalliferum, refers to the abundance of crystals in the wood.

Remarks.-The genus Parametopioxylon n. gen. resembles Metopium (see Terrazas, 1994; InsideWood, 2004-onwards). It was compared with fossil genera assigned to Anacardiaceae, but shows distinct diagnostic features: diffuse to semi-ring-porous, vessels without arrangement or in a somewhat diagonal pattern, abundant tyloses, simple perforation plates, alternate-to-opposite intervessel pitting, heterocellular rays, some multiseriate rays with canals and reaching a height of $>500 \mu \mathrm{m}$, axial parenchyma paratracheal predominantly vasicentric, sometimes confluent, aliform, and apotracheal marginal, prismatic crystals in upright/ square and procumbent ray cells.

When our material is scored for the presence of growth rings (1p), wood diffuse-porous (5p), simple perforation plates (13p), alternate intervessel pits (22p), tyloses (56p), gums and other deposits in heartwood vessels (58p), simple to minutely bordered pits in fibers (61p), vasicentric (79p), axial parenchyma in marginal or in seemingly marginal bands (89p), rays width 1-3 wide (97p), radial canals (130p), prismatic crystals (136p) in upright or square (137p) and procumbent ray cells (138p) and absence of vessels in tangential bands (6a) or in dendritic pattern (8a), vessels exclusively solitary (9a), vessels in radial multiples of 4 or more (10a), vessel clusters common (11a), scalariform perforation plates (14a), large intervessel pit (27a), axial parenchyma diffuse-in-aggregates (77a) or in bands more than three cells wide (85a) and ray height $>1 \mathrm{~mm}$ (102a), a search of the InsideWood database (2004-onward) returns Metopium sp. as the only modern wood that matches these characters. There are two features that are "variable" both in Parametopioxylon crystalliferum n. gen. n. sp. and in the extant genus Metopium: wood semi-ring-porous (4p) and vessels in diagonal and/or radial pattern (7p).

\section{Genus Astroniumxylon Brea, Aceñolaza, and Zucol, 2001}

Type species.-Astroniumxylon portmannii Brea, Aceñolaza, and Zucol, 2001 by original designation. Paraná Formation (late Miocene), Villa Urquiza, Entre Ríos Province, Argentina.

Astroniumxylon bonplandianum Franco, 2009 Figure 5.1, 5.2

Holotype.-CIDPALBO-MEG 27, from the Ituzaingó Formation, Toma Vieja, Entre Ríos Province, Argentina.

Occurrence.-Ituzaingó Formation (late Miocene? sensu Brunetto et al., 2013), outcropping in Toma Vieja (CIDPALBO-MEG 88) and Arroyo El Espinillo (CIDPALBO-MEG 91), Entre Ríos Province, Argentina. 


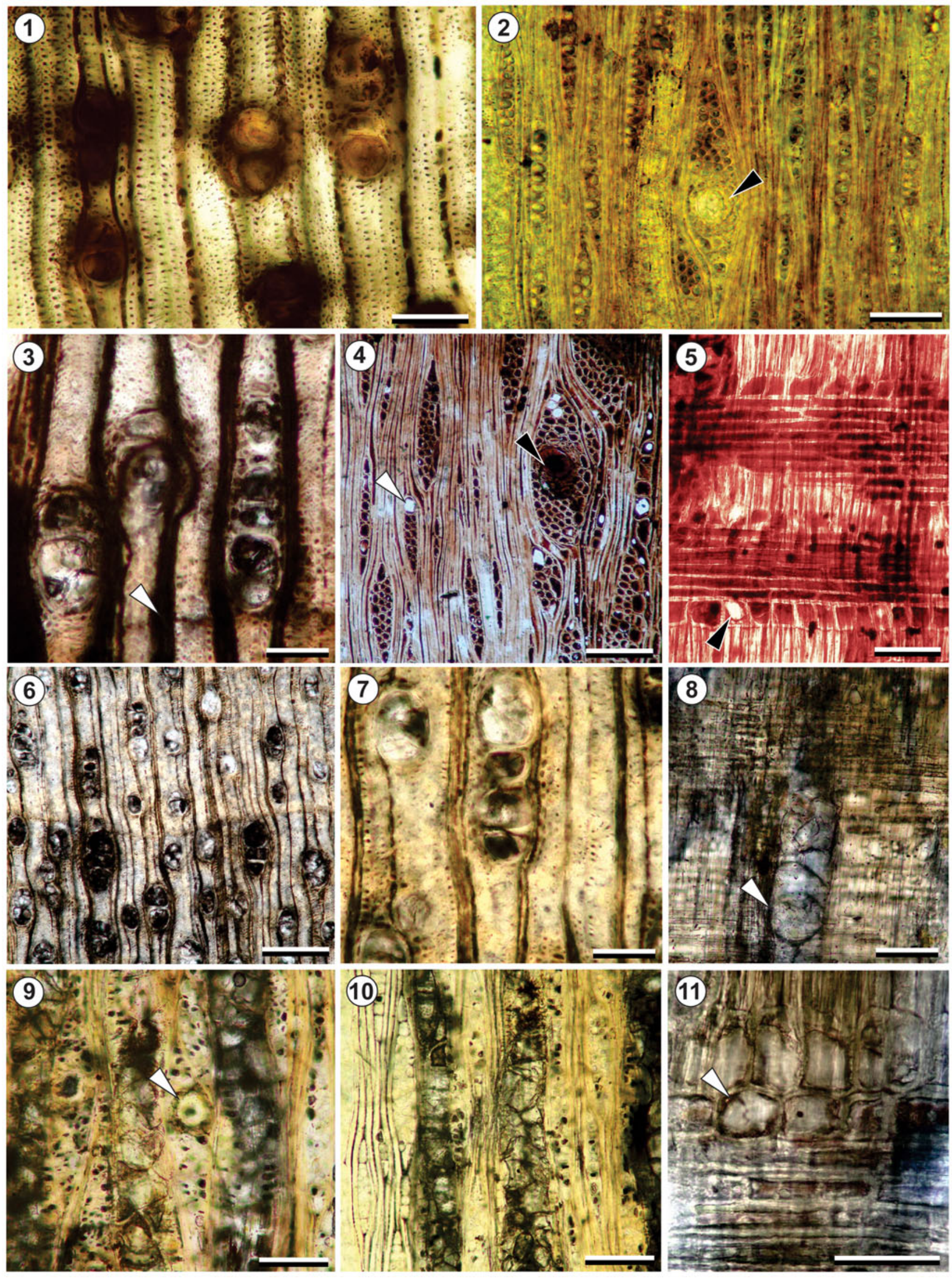


Figure 5. (1, 2) Astroniumxylon bonplandianum Franco, 2009, CIDPALBO-MEG 91: (1) Cross section showing vessels with tyloses, parenchyma paratracheal, and fibers in files radially oriented; (2) longitudinal tangential section showing linear rays mainly uniseriate and biseriate, and multiseriate ray with radial canal (arrow). (3-5) Astroniumxylon parabalansae Franco et Brea, 2008: (3) CIDPALBO-MEG 78, cross section showing vessels with tyloses and distinct growth ring (arrow); (4) CIDPALBO-MEG 81, longitudinal section showing rays mostly 1-3 seriate, multiseriate ray with radial canal (black arrow) and prismatic crystals in ray cells (white arrow); (5) CIDPALBO-MEG 81, longitudinal radial section showing heterocellular rays with one or two rows of square marginal cells, the arrow indicates a prismatic crystal. (6-12) Schinopsixylon herbstii Lutz, 1979 emended, CIDPALBO-MEG 70. (6) Cross section showing diffuse porosity and vessels with tyloses; (7) detail of vessels and scanty axial parenchyma in cross section; (8) general view of longitudinal radial section, the arrow indicates a simple perforation plate; $(\mathbf{9}, \mathbf{1 0})$, longitudinal tangential section showing rays and vessels, the arrow indicates a radial canal; (11), detail of longitudinal radial section showing heterocellular rays, the arrow indicates a prismatic crystal. Scale bars $(\mathbf{1 - 5 , 7 - 1 0 )} 100 \mu \mathrm{m} ;(\mathbf{6}) 300 \mu \mathrm{m} ;$ (11) $50 \mu \mathrm{m}$.

Description.-The fossil specimens are in a very good state of preservation; CIDPALBO-MEG 88 has a diameter of $9 \mathrm{~cm}$ and is $28 \mathrm{~cm}$ long, and CIDPALBO-MEG 91 has a diameter of 5 $\mathrm{cm}$ and is $11.5 \mathrm{~cm}$ long. Growth rings are distinct, demarcated by a change in fiber diameter. Vessels are diffuse porous and circular in cross section, with tyloses and other deposits. Vessels are mainly solitary (53\%), frequently in radial multiples of two $(31 \%)$, sporadically in radial multiples of three $(12 \%)$, rarely in radial multiples of more than three $(2 \%)$, in tangential multiples $(1 \%)$, and in clusters $(1 \%)$. The mean vessel tangential diameter is 72 (35-130) $\mu \mathrm{m}$ in CIDPALBO-MEG 88 and 47 (26-69) $\mu \mathrm{m}$ in CIDPALBO-MEG 91, and the mean vessel radial diameter is $36(12-71) \mu \mathrm{m}$ in CIDPALBO-MEG 88 and 66 (10-120) $\mu \mathrm{m}$ in CIDPALBO-MEG 91. The mean vessel element length is $166(100-245) \mu \mathrm{m}$. There are, on average, 30 (24-41) pores per $\mathrm{mm}^{2}$. The mean vessel wall thickness is $5(2-6) \mu \mathrm{m}$. Vessel elements have straight to oblique end walls. Perforation plates are simple. Intervessel pits are bordered, alternately arranged, with an average diameter of 7 (4-9) $\mu \mathrm{m}$. Vessel-ray pits have distinct borders and are like intervessel pits in size and shape throughout the ray cell. Fibers are polygonal to rounded in outline and arranged in radial rows. The mean fiber diameter is $13(7-18) \mu \mathrm{m}$ and the wall thickness is $4(3-5) \mu \mathrm{m}$. Fibers have simple to minutely bordered pits. Axial parenchyma is paratracheal, vasicentric, scanty, confluent. Rays are heterocellular with one or more rows of square marginal cells; mainly uniseriate (52\%) and biseriate $(38 \%)$, and sporadically multiseriate (10\%); 196 (40440) $\mu \mathrm{m}$ high and 24 (10-70) $\mu \mathrm{m}$ wide, 11 (2-22) cells high and two (1-4) cells wide. There are 10 (6-14) rays per linear $\mathrm{mm}$. Sheath cells are present. Prismatic crystals are present in rays. There are 1-2 radial canals in some multiseriate rays.

Materials.-CIDPALBO-MEG 88, CIDPALBO-MIC 1127; CIDPALBO-MEG 91, CIDPALBO-MIC 1130.

Remarks. - The new Ituzaingó material conforms to the specific diagnosis of Astroniumxylon bonplandianum.

Astroniumxylon parabalansae Franco and Brea, 2008

Figure 5.3-5.5

2010 Schinopsixylon heckii (Lutz); Brea, Zucol, and Patterer, p. 48 , pl. V, figs. 1-8.

2011 Incertae sedis; Franco, p. 220, fig. 7.42, 7.43.

Holotype.-CIDPALBO-MEG 22, from the Paraná Formation (late Miocene), Toma Vieja, Entre Ríos Province, Argentina.
Occurrence.-Ituzaingó Formation (late Miocene? sensu Brunetto et al., 2013) outcropping at Curtiembre (CIDPALBO-MEG 78 and 81) and Toma Vieja (CIDPALBO-MEG 29), Entre Ríos Province, Argentina.

Description.-The fossil specimens are in a very good state of preservation. CIDPALBO-MEG 29 is based on two fragments: the first one has a diameter of $7 \mathrm{~cm}$ and is $17.5 \mathrm{~cm}$ long, and the second one has a diameter of $3 \mathrm{~cm}$ and is $16 \mathrm{~cm}$ in long. CIDPALBO-MEG 81 has a diameter of $16 \mathrm{~cm}$ and is 19.5 cm long, and CIDPALBO-MEG 78 has a diameter of $8 \mathrm{~cm}$ and is $14 \mathrm{~cm}$ long. Growth rings are distinct, demarcated by marginal axial parenchyma. Vessels are diffuse porous. Vessels are circular in cross section with tyloses and other deposits. Vessels are mainly solitary (33\%), frequently in radial multiples of two $(32 \%)$, sporadically in radial multiples of three, four, five, and more elements $(16 \%, 6 \%$, $4 \%$, and $5 \%$, respectively), and in clusters $(4 \%)$. The mean vessel tangential diameter is $86(35-143) \mu \mathrm{m}$, and the mean vessel radial diameter is $64(10-133) \mu \mathrm{m}$ in CIDPALBO-MEG 78, 66 (10-120) $\mu \mathrm{m}$ in CIDPALBO-MEG 81 and 84 (63-103) $\mu \mathrm{m}$ CIDPALBO-MEG 29. The mean vessel element length is $171(50-300) \mu \mathrm{m}$. There are, on average, 24 (18-36) pores per $\mathrm{mm}^{2}$ in CIDPALBO-MEG 78 and CIDPALBO-MEG 81, and $11(6-13)$ pores per $\mathrm{mm}^{2}$ CIDPALBO-MEG 29. The mean vessel wall thickness is $6(4-10) \mu \mathrm{m}$ in CIDPALBO-MEG 78, 8 (4-18) $\mu \mathrm{m}$ in CIDPALBO-MEG 81, and 9 (6-14) $\mu \mathrm{m}$ in CIDPALBO-MEG 29. Vessel elements have straight to oblique end walls. Perforation plates are simple. Intervessel pits are circular, bordered, in alternate to subopposite arrangement, with an average diameter of 7 (6-9) $\mu \mathrm{m}$ in CIDPALBO-MEG 78 and CIDPALBO-MEG 81, and 4 (3-5) $\mu \mathrm{m}$ in CIDPALBO-MEG 29. Vessel-ray pits have much-reduced borders to apparently simple; pits are horizontal. Fibers are polygonal rounded in outline and arranged in radial rows. The mean fiber diameter is 12 (7-17) $\mu \mathrm{m}$ and the walls are 5 (3-6) $\mu \mathrm{m}$. Axial parenchyma is paratracheal, vasicentric, lozenge-aliform, confluent, septate. Axial parenchyma bands are more than three cells wide and marginal. Rays are heterocellular with one or two rows of square marginal cells. Rays are mainly triseriate $(32 \%)$, biseriate $(28 \%)$ and uniseriate $(25 \%)$, but tetraseriate $(8 \%)$ or more $(7 \%)$ occur. Rays are 189 (27-661) $\mu \mathrm{m}$ high and 26 (5-109) $\mu \mathrm{m}$ wide, nine (1-37) cells high and two (1-6) cells wide. There are $11(7-14)$ rays per linear mm. Prismatic crystals are present in upright and/or square and procumbent ray cells. Some multiseriate rays have 1-2 radials canals. 


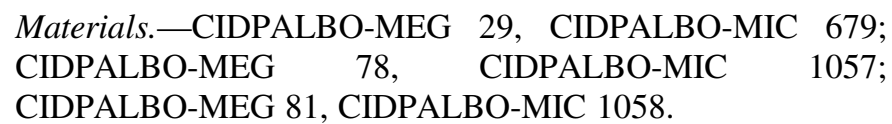

Remarks.-The new Ituzaingó material conforms to the specific diagnosis of Astroniumxylon parabalansae.

\section{Genus Schinopsixylon Lutz, 1979}

Type species.—Schinopsixylon herbstii Lutz, 1979 by original designation, from Ituzaingó Formation (late Miocene?), El Brete, Entre Ríos province, Argentina.

\section{Schinopsixylon herbstii Lutz, 1979 emended} Figure 5.6-5.11

1979 Schinopsixylon heckii Lutz, p. 44, figs. 7-10.

1999 Schinopsixylon heckii (Lutz); Brea, p. 64, figs. 2A-F, 3A-D.

2011 Schinopsixylon heckii (Lutz); Franco, p. 201, fig. 7.36-7.38.

Holotype.-PB-CTES 2925, from Ituzaingó Formation (late Miocene?), El Brete, Entre Ríos province, Argentina.

Emended specific diagnosis.—Diffuse porous; vessels solitary and in radial multiples of 2-3 (4-5); vessel elements moderately numerous and medium sized; bordered and alternate intervessel pitting; abundant tyloses; perforation plate exclusively simple; rays mostly multiseriate, rarely uniseriate and biseriate; rays heterocellular, composed of procumbent and upright cells; rays multiseriate with canals; paratracheal axial parenchyma vasicentric and scanty.

Occurrence.-Ituzaingó Formation (late Miocene? sensu Brunetto et al., 2013) in Planta Potabilizadora, Paraná city, Entre Ríos Province, Argentina.

Description.-The fossil specimen is in a good state of preservation and is based on two fragments: the first one has a diameter of $69 \mathrm{~cm}$ and is $141 \mathrm{~cm}$ long, and the second one has a diameter of $76 \mathrm{~cm}$ and is $222 \mathrm{~cm}$ long. Growth rings are distinct to indistinct. Vessels are diffuse porous. Vessels are circular in cross-section with tyloses and other deposits. Vessels are mainly solitary (67\%), frequently in radial multiples of two (17\%), sporadically in radial multiples of three and more elements (10\% and $4 \%$, respectively), and in clusters (2\%). The mean vessel tangential diameter is $80(46-111) \mu \mathrm{m}$ and the mean vessel radial diameter is $96(26-171) \mu \mathrm{m}$. The mean vessel element length is $176(85-275) \mu \mathrm{m}$. There are, on average, $12(8-15)$ pores per $\mathrm{mm}^{2}$. The mean vessel wall thickness is $11(7-20) \mu \mathrm{m}$. Vessel elements have oblique end walls. Perforation plates are simple. Intervessel pits are circular to polygonal in shape, bordered, and alternately arranged, with an average diameter of 7 (5-7) $\mu \mathrm{m}$. Vessel-ray pits have much-reduced borders to apparently simple; pits horizontal. Fibers are non-septate, polygonal in outline, and form the ground in radially oriented files. The mean fiber diameter is $12(8-18) \mu \mathrm{m}$ and the wall thickness is $5(3-7)$ $\mu \mathrm{m}$. Axial parenchyma is paratracheal, scanty, and vasicentric.
Rays are heterocellular; body cells are procumbent and square and upright cells are mixed throughout the ray. The rays are mainly tetraseriate $(28 \%)$ and triseriate $(25 \%)$, biseriate $(18 \%)$, uniseriate $(14 \%)$, pentaseriate $(12 \%)$, or more $(3 \%)$. Rays are $247(132-587) \mu \mathrm{m}$ high and $32(13-31) \mu \mathrm{m}$ in wide, 12 (434) cells high and three (1-6) cells wide. There are eight (611) rays per linear mm. Prismatic crystals are present in upright and/or square ray cells. Some multiseriate rays have 12 radial canals.

\section{Materials._CIDPALBO-MEG 70, CIDPALBO-MIC 1043.}

Remarks.-This specimen was coded according to IAWA convention for: presence of diffuse-porous wood (5p), simple perforation plates (13p), alternate intervessel pits (22p), tyloses (56p), non-septate fibers (66p), scanty paratracheal (78p) and vasicentric axial parenchyma (79p), rays $1-10$ cells wide (97p and 98p), radial canals (130p), prismatic crystals in upright and/or square ray cells (136p and 137p); and for absence of ring-porous (3a) or semi-ring-porous (4a) wood, vessels in tangential bands (6a), vessels in diagonal and/or radial pattern (7a), vessels in dendritic pattern (8a). A search of the InsideWood database based on this coding returned four matches: Astronium graveolens Jacquin, 1760; Astronium spp.; Schinopsis lorentzii (Grisebach) Engler, 1881; and Schinopsis spp.

Based on the presence of diffuse porous, vessels solitary and in radial multiples of 2-5, abundant tylosis, perforation plate exclusively simple, bordered and alternate intervessel pitting, paratracheal axial parenchyma vasicentric and scanty, rays uniseriate to multiseriate, heterocellular, and rays multiseriate with canals, our material most closely resembles the extant genus Schinopsis and conforms to the circumscription of the fossil species Schinopsixylon herbstii (Lutz, 1979). We therefore emended the specific diagnosis to include the presence of solitary vessels and the phrase "rays heterocellular composed of procumbent and upright cells."

\section{Multivariate analyses}

The cluster resulting from the analysis of 17 fossil specimens and four extant species shows three well-delimited groups: the first one is comprised by Metopium sp., PMET1 and PMET2; the second, by SCHK1, SCHT1, SCHK2, SCHK4 and Schinopsis balansae; and the third, Astronium balansae, Astronium urundeuva, all the specimens of Astroniumxylon and SCHK3 (Fig. 6.2). In this third group, it is possible to further distinguish three subgroups: the first one includes all the specimens of Astroniumxylon bonplandianum, the second has all the specimens of Astroniumxylon parabalansae and SCHK3, and the third includes Astronium balansae, Astronium urundeuva and Astroniumxylon portmannii.

The CA performed for the specimens indicates that the first four dimensions accounted for $63.781 \%$ of the total variation (Table 2). The first dimension accounts for $21.708 \%$ of the total variance (Table 2, Fig. 6). The characters that contributed most to the first dimension are: vessels in diagonal or dendritic pattern (3), porosity (2), shape (12) and arrangement (13) of intervessel pits, mean vessel element length (10), height of 
(1)

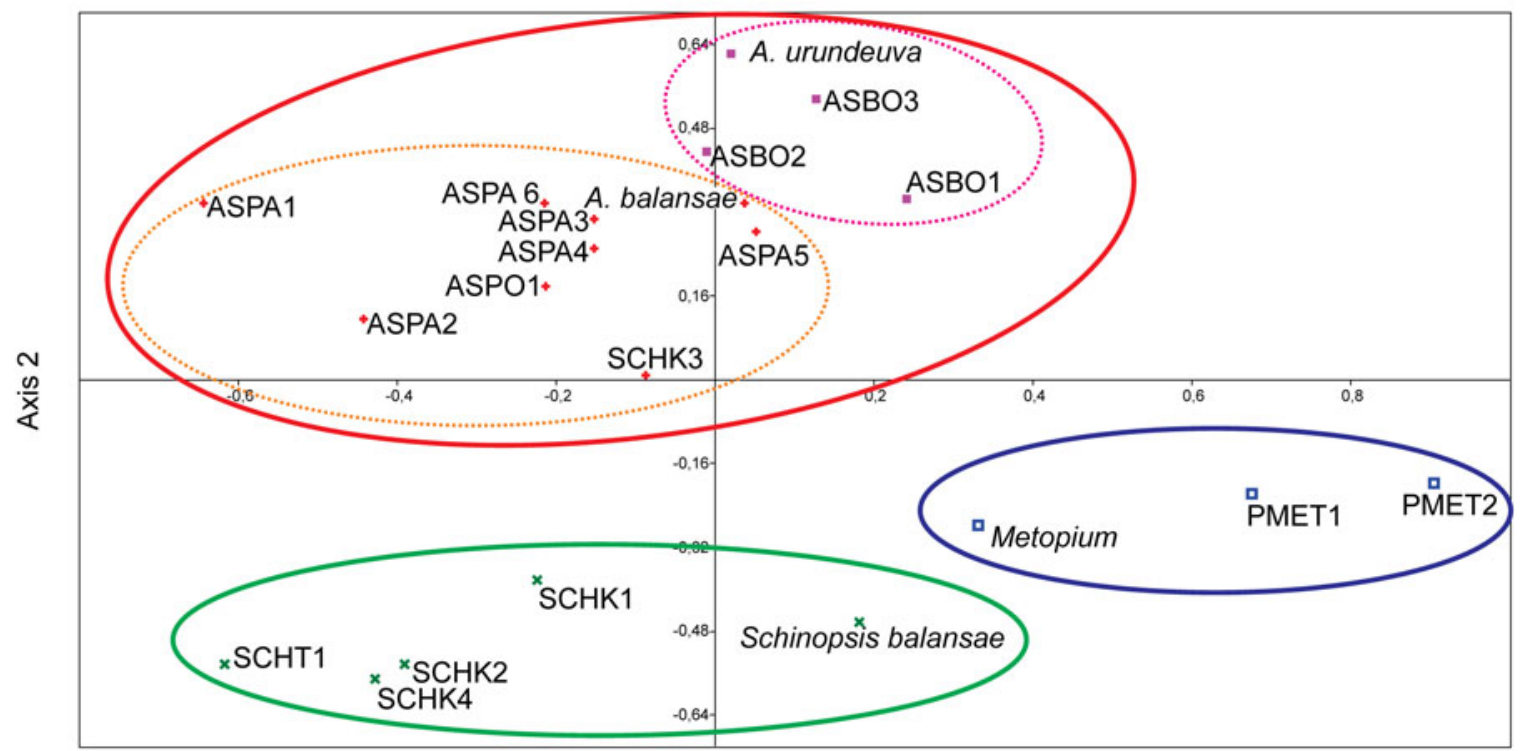

Axis 1

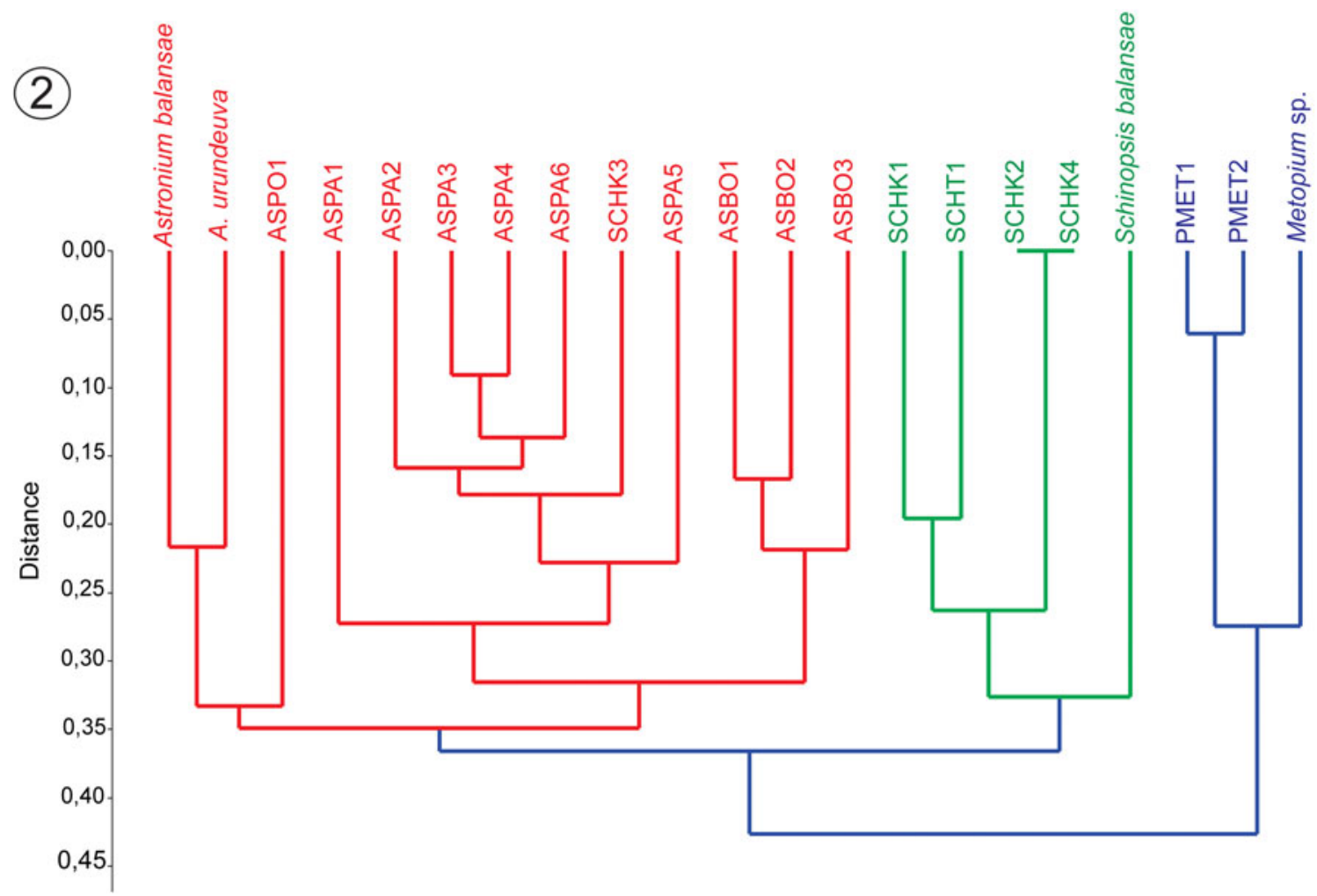

Figure 6. (1) Scatterplot of scores on Axis I versus Axis II from Correspondence Analysis (CA) of specimens analyzed (for OTU numbers see Table 1). (2) Cluster analysis constructed by means of UPGMA algorithm and Gower's Similarity Distance Coefficient (for OTU numbers see Table 1).

multiseriate rays and rays mostly $4-10$ seriate (32) (Supplementary Material 3). Four characters-height of multiseriate rays (28), and rays mostly 4-10 seriate (32), shape of intervessel pits (12), and vessels in diagonal or dendritic pattern (3) - contributed most to the second dimension, which accounts for $17.672 \%$ of the total variance (Table 2 and Supplementary
Material 3). Dimension three accounts for $12.801 \%$ of the total variance (Table 2); characters 13 (arrangement of intervessel pits), 10 (mean vessel element length), 29 (prismatic crystals in rays), and 30 (percentage of uniseriate rays) have the highest coefficients on this dimension (Supplementary Material 3). Dimension four accounted for $11.527 \%$ of the total variance; 
Table 2. List of the eigenvalue and variance explained for each of the first four dimensions of the Correspondence Analysis (CA).

\begin{tabular}{lccc}
\hline Dimension & Eigenvalues & Percentages & Cumulative percentages \\
\hline 1 & 0.168422 & 21.708 & 21.708 \\
2 & 0.137113 & 17.672 & 39.452 \\
3 & 0.0993202 & 12.801 & 52.264 \\
4 & 0.0894335 & 11.527 & 63.781 \\
\hline
\end{tabular}

the arrangement of intervessel pits (13), percentage of uniseriate rays (30), apotracheal axial parenchyma (19), rays mostly 4-10 seriate (32), and vessels arrangement in diagonal or dendritic pattern (3) contributed most to this dimension (Supplementary Material 3). Therefore, the best definition of groups is represented by axis 1 versus 2 (together they explained $39.452 \%$ of variance), and three groups are clearly distinguished (Fig. 6.1).

\section{Discussion}

Multivariate analyses.-According to the cluster analysis, the group formed by PMET1, PMET2 (both specimens of Parametopioxylon crystalliferum n. gen. n. sp.), and Metopium sp. shows the lowest dissimilarity with values lower than 0.30 . This is consistent with the fact that Parametopioxylon crystalliferum $\mathrm{n}$. gen. $\mathrm{n}$. sp. has more affinity with the descriptions made for Metopium sp. (see Terrazas, 1994; InsideWood, 2004-onwards).

Another group is made up of different specimens of Schinopsixylon and Schinopsis balansae. In 1979, Lutz created the genus Schinopsixylon and erected two species, S. herbstii and S. heckii. According to the diagnosis, $S$. heckii differs from $S$. herbstii by the presence of mostly solitary pores ( $80 \%$ solitary pores and $20 \%$ in radial multiples) and only one radial canal per ray (Lutz, 1979). Based on our multivariate analysis, we determined that the characters 5 and 33 (vessels mostly solitary and number of radial canals per ray, respectively; Supplementary Material 1 and 3) lack enough taxonomic value to justify the separation of the two species in Schinopsixylon (Fig. 6) and correspond to intraspecific variations. Thus we proposed that $S$. heckii is synonymous with $S$. herbstii (Table 3; Fig. 6). These results are consistent with wood anatomy and multivariate analyses carried out by Gimenez et al. (2015) in three species of extant Schinopsis (S. lorentzii, S. balansae, and S. marginata Engler, 1883). These authors did not observe differences in the 29 anatomical characters studied and proposed that Schinopsis wood anatomy is substantially homogeneous with only some differences found in quantitative variables as well as density, diameter, and length of the vessels, all resulting from ecological adaptations caused by altitudinal gradient (Gimenez et al., 2015).

The characters enabling the distinction between Schinopsixylon and Astroniumxylon are the presence of rays mostly 4-10 seriate, exclusively paratracheal axial parenchyma, rays $\geq 6$ cells wide common, and multiseriate rays commonly 301$400 \mu \mathrm{m}$ in height (Supplementary Material 3). Therefore, as a result of our multivariate analysis, we transfer CIDPALBOMEG 12 specimen (under the acronym SCHK3), previously assigned to Schinopsixylon heckii by Brea et al. (2010, see Table 1) to Astroniumxylon parabalansae on the basis of possessing apotracheal axial parenchyma and multiseriate rays $\leq 5$ cells wide, and of not possessing prismatic crystals and mostly 4-10 seriate rays (Table 3, Fig. 6, Supplementary Material 3).

The CA delimits a group composed of Astronium balansae, A. urundeuva, and all the fossil woods with affinity to these. Two subgroups can be differentiated inside of that one. One subgroup consists of A. urundeuva and Astroniumxylon bonplandianum fossils; the other subgroup consist of A. balansae, Astroniumxylon parabalansae, and A. portmannii fossils (Fig. 6.1). In the cluster analysis, the fossil groups mentioned above are delimited, the extant species and A. portmannii are not related to the subgroups as in the CA (Fig. 6.2). Astroniumxylon parabalansae and Astroniumxylon portmannii can be differentiate because the first one has vessels in radial multiples of 4 or more elements and height of multiseriate rays are $<300 \mu \mathrm{m}$.

Based on the multivariate analysis, ten variables are the most efficient in discriminating among species: porosity type (2), vessels arrangement (3), mean of vessel element length (10), shape (12) and arrangement (13) of intervessel pits, apotracheal axial parenchyma present (19), height of multiseriate rays (28), prismatic crystals in rays (29), percentage of uniseriate rays (30), and rays mostly 4-10 seriate (32). In the present paper, these characters are considered the most useful for delineating

Table 3. Proposal of reassignment of the fossil specimens using multivariate analysis.

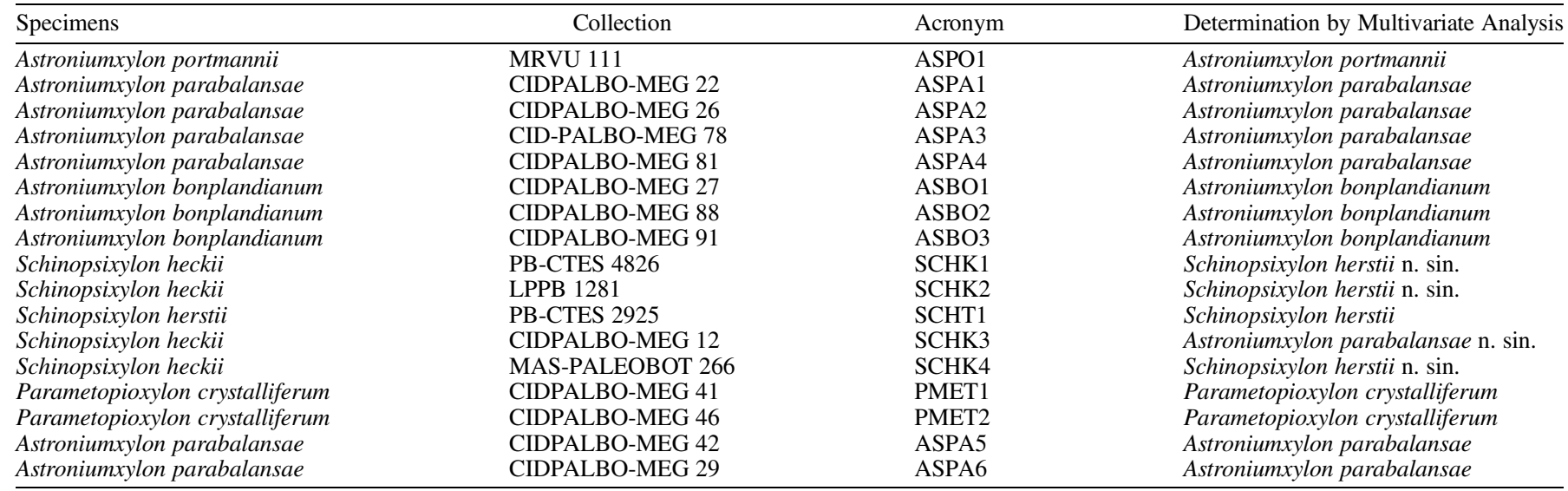


and circumscribing these fossil species. On the basis of our analyses, a diagnostic key for the species studied in this work is given:

1. a. Diffuse porous and vessels 2 without arrangement

b. Semi-ring-porous and vessels with tendency to diagonal arrangement

2. a. Rays mostly 4-10 seriate, multiseriate rays commonly 301-400 $\mu \mathrm{m}$ in height and parenchyma exclusively paratracheal

b. Rays mostly 1-3 seriate 3

3. a. Exclusively paratracheal parenchyma and percentage of uniseriate rays $\geq 31 \%$

b. Apotracheal and paratracheal axial parenchyma and percentage of uniseriate rays $\leq 31 \%$.

4. a. Absence of vessels in radial multiples of 4 or more elements and height of multiseriate ray $301-400 \mu \mathrm{m}$

b. Presence of vessels in radial multiples of 4 elements and height of multiseriate ray $\leq 300 \mu \mathrm{m}$

Paleoclimatic, paleoecology and paleobiogeography inferences. - The Anacardiaceae was an important component of the vegetation during the late Cenozoic in southernmost South America. This evidence is supported by the diverse and abundant Cenozoic fossil record of the family in this region.

Some peculiar features of the Anacardiaceae fossil woods, such as distinct growth rings, semi-ring-porous, radial canals, and scanty and paratracheal axial parenchyma, suggest a dry or seasonally dry warm climate. Others features present in some fossil woods from the Paraná Formation, such as wider vessels and low vessel frequency, suggest that some taxa were exceptionally adapted to humid conditions associated with riparian forests (see Brea and Franco, 2013 and references herein).

Comparisons with the nearest living relatives of the Paraná fossil woods can also provide insight into paleoclimate and paleoecology. The genus Metopium includes evergreen to semideciduous, medium-size trees, ranging from West Indies to Florida, Mexico, and Central America (Terrazas, 1994). This area corresponds to the Caribbean subregion sensu Morrone (2001) and is known as Halffter's Mexican Transition Zone (MTZ). The MTZ is a complex area where the Neotropical and Nearctic biotas overlap (Halffter and Morrone, 2017). The genus Astronium has endemic species with disjunct distribution throughout different areas in the Neotropical Dry Forests (Pennington et al., 2000), many of which are characterized by a strongly seasonal climate. Astronium urundeuva is an important member of the Caatingaas, a seasonal dry forest in north-eastern Brazil (Prado and Gibbs, 1993). Today, these genera do not occur where the fossils described here were collected. The finding of fossils with affinities to Metopium and Astronium affinity could be explained by a greater southward and eastward extent of Neotropical Dry Forests during the late Miocene than occurs today (Prado and Gibbs, 1993; Pennington et al., 2000; 2004; Prado, 2000, DRYFLOR, 2016; Flanklin et al., 2018). These results are consistent with the fact that during the late Miocene, large areas of the continents experienced drying, enhanced seasonality, and a restructuring of terrestrial plant and animal communities. These global climate changes are seen throughout the subtropics, but have been attributed to regional tectonic forcing (Herbert et al., 2016; Stevens Goddard and Carrapa, 2018).

\section{Conclusions}

A taxonomic revision and multivariate analyses were conducted on seventeen specimens of late Cenozoic Anacardiaceae fossil woods from northeastern Argentina and four extant species. Eight new silicified wood specimens assigned to four different species of the Anacardiaceae family were described: two specimens of Parametopioxylon crystalliferum $\mathrm{n}$. gen. $\mathrm{n}$. sp, three of Astroniumxylon bonplandianum, two of Astroniumxylon parabalansae, and one of Schinopsixylon heckii. Parametopioxylon crystalliferum n. gen. n. sp. has been erected based on exceptionally wellpreserved fossil woods recovered from the Ituzaingó Formation.

A correspondence analysis of 22 anatomical characters of anacardiaceous woods was conducted. Taxonomically relevant characters, anatomical variability, and relationships among Anacardiaceae species were identified using correspondence and cluster analyses and allowed us to differentiate and revise the Anacardiaceae genera and species included in this paper. Schinopsixylon heckii Lutz, 1979 and Schinopsixylon herbstii Lutz, 1979 are not clearly segregated and can be explained by intraspecific or individual variability; we propose that $S$. heckii is synonymous of $S$. herbstii. Schinopsixylon could be distinguished from Astroniumxylon by the presence of mostly 4-10 seriate rays, commonly $\geq 6$ cells wide, $301-400 \mu \mathrm{m}$ in height, and axial parenchyma exclusively paratracheal. A taxonomic key is proposed in this paper to differentiate anacardiaceous fossil woods found in the late Cenozoic of northeastern Argentina.

Lastly, in accordance to previous studies, wood anatomy suggests that in the late Cenozoic, Anacardiaceae were linked to a dry or seasonally dry warm climate, with some trees and shrubs adapted to xeric conditions and seasonality and others exceptionally adapted to humid conditions associated with riparian forests.

\section{Acknowledgments}

The authors are grateful to A. Zucol, E. Passeggi, and C. Piña for their constructive and valuable comments, suggestions, and discussions during the preparation of this paper. This paper was financially supported by Agencia Nacional de Promoción Científica y Tecnológica PICT 2008-0176 (M. Brea and A.F. Zucol) and PICT 2014-1758 (M.J. Franco); FCyT-UADER PIDIN 2016 234-16 (M.J. Franco) and Consejo Nacional de Investigaciones Científicas y Tecnológicas PIP-CONICET 11220130100245CO 
(M. Brea and M.J. Franco). The authors would like to express their thanks to the anonymous reviewers and editors for their valuable help in providing critical and constructive comments.

\section{Accessibility of supplemental data}

Data available from the Dryad Digital Repository: https://doi. org/10.5061/dryad.x95×69pd3.

\section{References}

Agarwal, M., and Gupta, S., 2008, Wood Anatomy of Sapindales: Dehra Dun, India, Bishen Singh Mahendra Pal Singh, $172 \mathrm{p}$.

Anzótegui, L.M., 1990, Estudio Palinológico de la Formación Paraná (Mioceno Superior) "Pozo Josefina," Provincia de Santa Fe, Argentina. II parte: paleocomunidades: Facena, v. 9, p. 75-86.

Anzótegui, L.M., and Aceñolaza, P.G., 2008, Macrofloristic assemblage of the Paraná Formation Middle-Upper Miocene) in Entre Ríos (Argentina): Neues Jahrbuch fur Geologie und Paläontology, v. 248, p. 159-170.

APG IV., 2016, An update of the Angiosperm Phylogeny Group classification for the orders and families of flowering plants: APG IV: Botanical Journal of the Linnean Society, v. 181, p. 1-20.

Avise, J.C., and Johns, G., 1999, Proposal for a standardized temporal scheme of biological classification for extant species: Proceedings of the National Academy of Sciences, v. 96, p. 7358-7363.

Baas, P., and Wheeler, E.A., 2011, Wood anatomy and climate change. Chapter 6, in Hodkinson, T., Jones, M., Waldren, S., and Parnell, J., eds., Climate Change, Ecology and Systematics: Cambridge, Cambridge University Press, p. 141-155.

Berchtold, B.V. von, and Presl, C.B., 1820, O Prirozenosti Rostlin aneb Rostlinar: Prague, Krala Wiljma Endersa, p. 266.

Brea, M., 1999, Leños fósiles de Anacardiaceae y Mimosaceae de la Formación El Palmar (Pleistoceno superior), del Departamento Concordia, provincia de Entre Ríos: Ameghiniana, v. 36, p. 63-69.

Brea, M., and Franco, M.J., 2013, El registro fósil de Anacardiaceae en el Cenozoico Tardío del Noreste argentino: Acta Geológica Lilloana, v. 25, p. 21-36.

Brea, M., and Zucol, A.F., 2011, The Paraná-Paraguay Basin: geology and paleoenvironments, in Albert, J., and Reis, R., eds., Historical Biogeography of Neotropical Fresh Water Fishes: Londres, University of California Press, p. 69-87.

Brea, M., Aceñolaza, P.G., and Zucol, A.F., 2001, Estudio paleoxilológico en la Formación Paraná, Entre Ríos, Argentina. XI Simposio Argentino de Paleobotánica y Palinología: Asociación Paleontológica Argentina, Publicación Especial, v. 8, p. 7-17.

Brea, M., Zucol, A.F., and Patterer, N., 2010, Fossil woods from late Pleistocene sediments from El Palmar Formation, Uruguay Basin, eastern Argentina: Review of Palaeobotany and Palynology, v. 163, p. 35-51.

Brown, R., 1818, Observations, systematical and geographical, on Professor Christian Smith's collection of plants from the vicinity of the River Congo, in Tuckey, J.H., ed., Narrative of an expedition to explore the River Zaire: London, John Murray, p. 420-485.

Browne, P., 1756, The Civil and Natural History of Jamaica in Three Parts: London, Osborn \& Shipton, 503 p.

Brunetto, E., Noriega, J.I., and Brandoni, D., 2013, Sedimentología, estratigrafía y edad de la Formación Ituzaingó en la provincia de Entre Ríos, Argentina, in Brandoni, D., and Noriega, J.I., eds., El Neógeno de la Mesopotamia Argentina: Publicación Especial de la Asociación Paleontológica Argentina No. 14, p. $13-27$.

Collinson, M.E., 1986, Use of modern generic names for plants fossils, in Spicer, R.E., and Thomas, B.A., eds., Systematic and Taxonomic Approaches in Palaeobotany: Systematics Association Special Volume 31, p. 91-104.

Crisci, J., and López Armengol, M.F., 1983, Introducción a la teoría y práctica de la taxonomía numérica: Secretaría General de la Organización de los Estados Americanos, Monografía No. 26, Washington, DC, 132 p.

DRYFLOR, 2016, Plant diversity patterns in neotropical dry forests and their conservation implications: Science, v. 353, p. 1383-1387. doi:10.1126/ science.aaf5080

Engler, A., 1881, Uber die morphologischen Verhältnisse und die geographische Verbreitung der Gattung Rhus, wie der mit ihr verwandten, lebenden und ausgestorbenen Anacardiaceae: Botanische Jahrbücher für Systematik, Pflanzengeschichte und Pflanzengeographie, v. 1, p. 365-426.

Engler, A., 1883, Burseraceae et Anacardiaceae, in De Candolle, A.L.P., and De Candolle, A.C., Monographiae Phanerogamarum 4: Paris, Sumptibus G. Masson, 464 p.
Engler, A., 1885, Eine neue Schinopsis: Botanische Jahrbücher für Systematik, Pflanzengeschichte und Pflanzengeographie, v. 6, p. 286.

Engler, H.G.A., 1876, Anacardiaceae: Flora Brasiliensis, v. 12, p. 367-418.

Franco, M.J., 2009, Leños fósiles de Anacardiaceae en la Formación Ituzaingó (Plioceno), Toma Vieja, Paraná, Entre Ríos, Argentina: Ameghiniana, v. 46, p. 587-604.

Franco, M.J., 2011, Estudios paleobotánicos de la Formación Ituzaingó (Plioceno-Pleistoceno), Cuenca del Río Paraná, Argentina [PhD thesis]: Córdoba, Facultad de Ciencias Exactas, Físicas y Naturales, Universidad Nacional de Córdoba, 368 p.

Franco, M.J., and Brea, M., 2008, Leños fósiles de la Formación Paraná (Mioceno medio), Toma Vieja, Paraná, Entre Ríos, Argentina: registro de bosques secos mixtos: Ameghiniana, v. 45, p. 699-718.

Franco, M.J., Brea, M., Orfeo, O., Zucol, A.F., 2013, La Paleoflora de la Formación Ituzaingó (PliocenoPleistoceno), Argentina, in Brandoni, D., and Noriega, J.I., eds., El Neógeno de la Mesopotamia Argentina. Publicación Especial 14. Buenos Aires, Asociación Paleontológica Argentina, p. 41-55.

Franklin, J., Andrade, R., Daniels, M., Fairbairn, P., Gillespie, T., Gonzalez, G., Gonzalez, O., Imbert, D., Kapos, V., Kelly, D.L., Marcano-Vega, H., Meléndez-Ackerman, E.J., McLaren, K.P., McDonald, M.A., Ripplinger, J., Rojas-Sandoval, J., Ross, M.S., Ruiz, J., Steadman, D.W., Tanner, E.V.J., Terrill, I., and Vennetier, M., 2018, Geographical ecology of dry forest tree communities in the West Indies: Journal of Biogeography, v. 45 , p. $1168-1181$.

Giménez, A.M., Calatayu, F., Diaz Zirpolo, J., Figueroa, M.E., and Gonzalez, D., 2015, Anatomía comparada del leño de tres especies nativas de Schinopsis (Anacardiaceae): Boletín de la Sociedad Argentina de Botánica, v. 50, p. 323-335.

Gregory, M., 1994, Bibliography of systematic wood anatomy of dicotyledons: IAWA Journal, Supplement, v. 1, p. 1-265.

Gregory, M., Poole, I., and Wheeler, E.A., 2009, Fossil dicot wood names: an annotated list with full bibliography: IAWA Journal, Supplement, v. 6, p. $1-220$.

Gupta, S., and Agarwal, M., 2008, Wood anatomy of Anacardiaceae from India with special reference to the systematic position of Rhus: IAWA Journal, v. 29, p. $79-106$.

Halffter, G., and Morrone, J.J., 2017, An analytical review of Halffter's Mexican transition zone, and its relevance for evolutionary biogeography, ecology and biogeographical regionalization: Zootaxa, v. 4226, p. 1-46.

Hammer, Ø., Harper, D.A.T., and Ryan, P.D., 2001, PAST: Paleontological statistics software package for education and data analysis: Palaeontologia Electronica, v. 4, no.1, p. 1-9. http://palaeo-electronica.org/2001_1/past/ issue1_01.htm

Heimsch, C., 1942, Comparative anatomy of the secondary xylem in the "Gruinales" and "Terebinthales" of Wettstein with reference to taxonomic grouping: Lilloa, v. 18, p. 83-198.

Herbert, T.D., Lawrence, K.T., Tzanova, A., Peterson, L.C., Caballero-Gill, R., and Kelly, C.S., 2016, Late Miocene global cooling and the rise of modern ecosystems: Nature Geoscience, v. 9, p. 843-847.

IAWA Committee., 1989, IAWA list of microscopic feature for hardwood identification: International Association of Wood Anatomists, Bulletin, v. 10, p. 219-332.

InsideWood., 2004-onwards, http://insidewood.lib.ncsu.edu/search [Sept 2017].

Jacquin, N.J., 1760, Enumeratio systematica plantarum, quas in insulis Caribaeis vicinaque Americes continente detexit novas, aut jam cognitas emendavit: Zug, Switzerland, Inter Documentation Company AG, 46 p.

Lutz, A.I., 1979, Maderas de Angiospermas (Anacardiaceae y Leguminosae) del Plioceno de la Provincia de Entre Rios, Argentina: Facena, v. 3, p. 39-63.

Martínez, L.C.A., and Pujana, R.R., 2010, Sobre la presencia de Resinaxylon schinusoides Pujana en la Formación San Julián (Oligoceno), Santa Cruz, Patagonia Argentina: Ameghiniana, v. 47, p. 535-539.

Martínez Millán, M., 2000, Biogeografía histórica (Terciario y Cuaternario) de Anacardiaceae con base en caracteres anatómicos de la madera [Bachelor Thesis]: Mexico City, Universidad Nacional Autónoma de México, 72 p.

Metcalfe, C.R., and Chalk, L., 1950, Anatomy of the Dicotyledons v. 2: Oxford, Claredon Press, $1500 \mathrm{p}$

Morrone, J.J., 2001, Biogeografía de América Latina y el Caribe. Manueles y Tesis 3: Zaragoza, España, Sociedad Entomológica Aragonesa, 148 p.

Muñoz, J.D., 2000, Anacardiaceae, in: Hunziker, A.T., ed., Flora Fanerogámica: Proflora, Córdoba No. 65, p. 1-28.

Passalia, M.G., Caviglia, N., and Vera, E.I., 2019, Lithraea australis (Berry) comb. nov. (Anacardiaceae) from the upper section of Nirihuau Formation (middle Miocene), Patagonia: Review of Paleobotany and Palynology, v. 266 , p. $1-11$.

Pennington, R.T., Prado, D.E., and Pendry, C.A., 2000, Neotropical seasonally dry forest and Quatenary vegetation changes: Journal of Biogeography, v. 27 , p. $261-273$. 
Pennington, R.T., Lavin, M., Prado, D.E., Pendry, C.A., Pell, S.K., and Butterworth, C.A., 2004, Historical climate change and speciation: neotropical seasonally dry forest plants show patterns of both Tertiary and Quaternary diversification: Philosophical Transactions of the Royal Society of London. Series B. Biological Sciences, v. 359, p. 515-538.

Poole, I., 2002, Systematics of Cretaceous and Tertiary Nothofagoxylon: implications for Southern Hemisphere biogeography and evolution of the Nothofagaceae: Australian Systematic Botany, v. 15, p. 247-276.

Prado, D.E., 2000, Seasonally dry forest of tropical South America: from forgotten ecosystems to a new phytogeographic unit: Edinburgh Journal of Botany v. 57 , p. $437-461$.

Prado, D.E., and Gibbs, P.E., 1993, Patterns of species distributions in the dry seasonal forests of South America: Annals of the Missouri Botanical Garden, v. 80, p. 902-927.

Pujana, R.R., 2009, Fossil woods from the Oligocene of southwestern Patagonia (Río Leona Formation). Atherospermataceae, Myrtaceae, Leguminosae and Anacardiaceae: Ameghiniana v. 46, p. 523-535.

Pujana, R.R., Martínez, L.C.A., García Massini, J.L., Di Orio, O., and Penas Steinhardt, A., 2014a, Legume (Mimosoideae) fossil woods from the Late Miocene (Salicas Formation) of Northwestern Argentina: Revista Brasileira de Paleontologia, v. 17, p. 317-326.

Pujana, R.R., Santillana, N.S., and Marenssi, S.A., 2014b, Conifer fossil woods from the La Meseta Formation (Eocene of Western Antarctica): evidence of Podocarpaceae- dominated forests: Review of Palaeobotany and Palynology, v. 200, p. 122-137.

Schweingruber, F.H., Börner, A., and Schulze, E.D., 2011, Atlas of Stem Anatomy in Herbs, Shrubs and Trees. Volume 1: Berlin, Heidelberg, SpringerVerlag, $425 \mathrm{p}$.

Stevens Goddard, A., and Carrapa, B., 2018, Effects of Miocene-Pliocene global climate changes on continental sedimentation: a case study from the southern Central Andes: Geology v. 46, p. 647-650.

Stevens, P.F., 2001-onwards, Angiosperm Phylogeny Website, Version 9. http://www.mobot.org/MOBOT/research/APweb/ [June 2018]

Terrazas, T., 1994, Wood anatomy of the Anacardiaceae: ecological and phylogenetic interpretation [PhD. Thesis]: Chapel Hill, NC, University of North Carolina, $321 \mathrm{p}$.

Terrazas, T., 1999, Anatomía de la madera de Anacardiaceae con énfasis en los géneros americanos: Boletín de la Sociedad Botánica de México, v. 64, 103-109.

Terrazas, T., and Wendt, T., 1995, Systematic wood anatomy of the Genus Tapirira Aublet (Anacardiaceae)—a numerical approach: Brittonia, v. 47, p. 109-129.

Tortorelli, L.A., 1956, Maderas y bosques argentinos: Buenos Aires, Editorial Acme, 515 p.

Wagemann, W., 1948, Maderas Chilenas. Contribución a su anatomía e identificación: Lilloa v. 16, p. 263-375.

Wheeler, E.A., 2011, InsideWood-a web resource for hardwood anatomy: IAWA Journal, v. 32, p. 199-211.

Zuloaga, F.O., and Morrone, O., 1999, Catálogo de las Plantas Vasculares de la Argentina: Dicotyledoneae Monographs in Systematic Botany, Missouri Botanical Garden, v. 74, p. 1-1246.

Accepted: 29 October 2019

\section{Appendix}

\section{List of all taxa used in the multivariate analyses}

Genus Parametopioxylon n. gen.

Parametopioxylon crystalliferum n. gen. $\mathrm{n}$. sp.

Holotype: CIDPALBO-MEG 41 (see Figs. 2-5 in this work)

Type stratigraphic horizon and age: Ituzaingó Formation, late Miocene?

Type fossil locality: Toma Vieja, Entre Ríos, Argentina.

Coding in this paper: PMET1.

Paratype: CIDPALBO-MEG 46, CIDPALBO-MIC 696.

Type stratigraphic horizon and age: Ituzaingó Formation, late Miocene?

Type fossil locality: Toma Vieja, Entre Ríos, Argentina.

Coding in this paper: PMET2.
Genus Astroniumxylon Brea, Aceñolaza, and Zucol, 2001

Type species: Astroniumxylon portmanii Brea, Aceñolaza, and Zucol, 2001

Holotype. MRVU 111 (see figs. 3.A-D and 4.A-D in Brea et al., 2001).

Type stratigraphic horizon and age: Paraná Formation, late Miocene.

Type fossil locality: Villa Urquiza, Entre Ríos, Argentina.

Coding in this paper: ASPO1.

Astroniumxylon parabalansae Franco and Brea, 2008

Holotype: CIDPALBO-MEG 22 (see fig. 4.1-4.8 in Franco and Brea, 2008).

Type stratigraphic horizon and age: Paraná Formation, late Miocene.

Type fossil locality: Toma Vieja, Entre Ríos, Argentina.

Coding in this paper: ASPA1.

Additional materials:

2009 Astroniumxylon parabalansae Franco and Brea in Franco, Ameghiniana 46: 587-604, 593, fig. 5.1-8 and 6.1-4 and in Franco, PhD Thesis: 1-343,188, fig. 7.33 and 7.35.

Material: CIDPALBO-MEG 26.

Coding in this paper: ASPA2.

2011 Astroniumxylon parabalansae Franco and Brea in Franco, PhD Thesis: 1-343,188, fig. 7.34 (CID-PALBO 78, CIDPALBO 81).

Material: CIDPALBO-MEG 78.

Coding in this paper: ASPA3.

Material: CIDPALBO-MEG 81.

Coding in this paper: ASPA4.

This paper. Astroniumxylon parabalansae Franco and Brea in this work.

Material: CIDPALBO-MEG 29.

Coding in this paper: ASPA6.

Synonyms:

2010 Schinopsixylon heckii Lutz in Brea et al., 2010, Review of Palaeobotany and Palynology 163: 35-51, 48, pl. V 1-8.

Material: CIDPALBO-MEG 12.

Coding in this paper: SCHK3.

2011. Insertae sedis 1 Franco, PhD Thesis: 1-343, 220, fig. 7.42-7.43 (CID-PALBO 42).

Coding in this paper: ASPA5

Astroniumxylon bonplandianum Franco, 2009

Holotype: CIDPALBO-MEG 27 (see fig. 3.1-3.6

and 4.1-4.7 in Franco, 2009).

Type stratigraphic horizon and age: Ituzaingó Formation, late Miocene?

Type fossil locality: Toma Vieja, Entre Ríos, Argentina.

Coding in this paper: ASBO1.

Additional material:

2011 Astroniumxylon bonplandianum Franco in Franco, PhD

Thesis: 1-343,184.

Material: CIDPALBO-MEG 88.

Coding in this paper: ASBO2. 
2011 Astroniumxylon bonplandianum Franco in Franco, PhD Thesis: 1-343,184.

Material: CIDPALBO-MEG 91.

Coding in this paper: ASBO3.

Genus Schinopsixylon Lutz, 1979.

Type species: Schinopsixylon herbstii, Lutz 1979.

Holotype: PB-CTES 2925 (see figs. 1-6 in Lutz, 1979).

Type stratigraphic and age: Ituzaingó Formation, late Miocene?

Type fossil locality: El Brete, Entre Ríos, Argentina.

Coding in this paper: SCHT1.

Synonyms:

1979 Schinopsixylon heckii Lutz, 1979, Facena 3: 39-63, 44, fig. 7-10.
Material: PB-CTES 4826

Coding in this paper: SCHK1.

1999 Schinopsixylon heckii Lutz in Brea, 1999, Ameghiniana 36: 63-69, 64, fig. 2.A-F, 3.A-D.

Material: LPPB 1281.

Coding in this paper: SCHK2.

2011 Schinopsixylon heckii Lutz in Franco, PhD Thesis: 1-343, 201, fig.7.36-7.38.

Material: MAS PALEOBOT 266 and CIPALBO-MEG 70 (isotype).

Coding in this paper: SCHK4. 